\title{
Will the Internationally Recognizable Country Identity of Slovakia "Work" or will the Current Attempts at Unifying the Presentation of Slovakia Abroad and the Search for an Attractive Narrative End in Failure
}

\author{
Mgr. Andrej Kóňa \\ Mgr. Jakub Hollý \\ The Faculty of Mass Media Communication, University of Ss. Cyril and Methodius in Trnava \\ andrej@kona-slovakia.eu, jakub.a.holly@gmail.com
}

\section{Doi:10.5901/mjss.2015.v6n6s1p368}

\section{Abstract}

Nation Branding, a political and social phenomenon of the past twenty years, is often incorrectly interpreted or even reduced to country promotion. Although its history is distinctively longer, it has attracted greater attention, especially after the fall of Iron Curtain, the change of political and power structures in Europe and the recodification of relations among the countries of the western and eastern parts of the continent.

Keywords: Nation Brand, Slovak Republic, tourism, brand identity, investments

\section{Introduction}

In 2015, the Slovak Republic celebrates 22 years of independence, and the functioning of a modern state which after the Velvet Revolution tried to stand on its own feet, and experienced several missteps (even reputational), as well as successes, particularly related to integration in international structures and attracting direct foreign investments. Nevertheless, Slovakia lags behind its neighbors in many areas; according to Zaušková (2010, p. 43), " in the evaluation of PRO INNO (2009), which assesses the innovative performance of countries, we are included in the bottom group of "catching up countries" with a summary innovation index of 0.25 (the EU average is 0.45 )". Similar results are also presented in Simon Anholt's Nation Brand Index, where Slovakia ranks among the last countries.

The development of the Slovak Republic has deeper roots that are not defined only by its close co-existence with the Czech nation throughout most of the $20^{\text {th }}$ century. The Empire of Samo (the $7^{\text {th }}$ century) and the Principality of Nitra (at the beginning of the $9^{\text {th }}$ century) are some of the most famous fragments of its early history. But how are all of the facts of the development of this country reflected in improving the positive awareness about the Slovak Republic and its populace of the $21^{\text {st }}$ century? How does our past in the Austro-Hungarian Empire affect the perception of our identity? Or more topically - why does violinist Niel Amstrong think that Peter Sagan, our best known cyclist, is a native of Slovenia?

\section{Nation Brand of Countries}

The academic community and experience have proved that you are either a traveler who thinks about which country to visit next or you are a company interested in expanding to or investing in a different country, and in the vast majority of cases, your decision is affected of the awareness of the country and feeling it evokes in you. For decades, many countries have worked on their image and brand strategic management. Israel is a good example - although no name was directly ever put on it - this country has maintained and created its image since the death of Jesus Christ. Other countries also nurture their brand. To this day, France creates a feeling of charm, luxury and love, Switzerland promotes its precision and scientific approach, Germany touts its technological skills and Italy is connected with art and historical monuments. All of these countries have been defined by their territorial integrity for centuries. But what about Slovakia?

Brand should be strategically managed with reference to values and feelings which it not only creates but also provides to its recipient. This is not a soulless graphic design. Therefore, the message related to this brand must also be meaningful and based on demonstrable or verifiable attributes. It is possible to overrate a brand for a short period of time. At best, the society which promoted the brand can top up the difference between the actual value and the value which is offered through its brand. At worst, respondents will eventually discover or become aware of this difference which can 
lead to hatred for this brand.

But what is the situation with a country brand? First of all, we have to realize the striking difference between the branding of a person, a society and a country. While in the first two cases, the basic attributes can be adjusted (change the color of the hair, the forms of expression, the corporate culture or factory appearance), this is impossible for a country; or it is impossible to actually control the brand identity. Its image cannot be based on attracting tourists to crystal-clear seas if it is situated in the mountains far from any salt water. We must work with attributes that are available or which can be created or changed.

The people living in a given country are the second most important factor. This also includes the government. When creating country branding, the nation's people must be taken into consideration. Because they are the bearers of the brand. If the citizens led by the government fail to identify with the promoted values, it is impossible for the country to successfully apply the branding in real life. The age of the populace must also been taken into consideration when applying branding. First of all - older people are less adaptable and have different values which could be at variance with the values the state strives to promote (older farmers will only grudgingly accept the technological features of their country). Simon Anholt, the founder of Nation Brand, says that in some cases, the incorrect application of country branding can take up to 50 years to undo. His words are also confirmed by MICE expert Pádriac Gilligan, who claims that the success of branding depends on the people living in the country and their approach.

The Slovak Government began to actively talk about the designing of a brand as a comprehensive matter promoting the country in 2009, when the Government Council for unified presentation was established. Three years later, the competences related to designing Slovakia's brand were transferred to the Ministry of Foreign and European Affairs (hereinafter referred to as the "MoFEA SR") through governmental regulation and legislation (the Competence Act). This Act refers to the completion of the unified system of the presentation of Slovakia abroad with a special emphasis on the synergy of cultural values, economic interests and support for tourism. For another three years, the MoFEA SR plans to launch a tender for the designing of a unified brand for Slovakia. This was preceded by several expert studies, including two mutually related studies compiled at the University of St. Cyril and Methodius in Trnava (UCM). The result of the second study is the preparation of materials for the aforementioned tender.

\section{The Right Time}

Has the time come to take this relatively big step? Or, is this an unnecessarily extended status that will result in decreasing numbers of tourists and investments in Slovakia? Several branding and tourism experts have grappled with this question. However, it is generally believed that the building of a country brand affects several areas of public life. According to Bobovnický (2011, p. 86), "The branding of products and services from places and the branding of the places themselves will increasingly be seen as a key focus of marketing, as well as a crucial component of foreign and domestic policy, international relations, economic and cultural development, trade and tourism".

The last work compiled by UCM's Faculty of Mass Media Communication was based on a questionnaire located on its website along with a blog (video and text) of various famous people (Simon Anholt also made his statement regarding Slovak branding among others), where the citizens and population and other involved parties could directly give their opinions regarding the branding. The authors of this project have registered over five hundred respondents in total, the vast majority of whom are young people between nineteen to twenty five years of age. Respondents were asked for their opinion regarding iconic places in Slovakia which should promote the country; the most frequent response was the Tatras (mountain range in the north of country), Bratislava (the capital) and Kriván (a peak in the High Tatras mountain range considered as a symbol of the nation). The survey also pertains to personalities (historical and contemporary) who have significantly influenced the creation of the country's image.

In its conclusion, this document refers to the necessity to look for a competitive product that would help Slovakia establish itself among other countries and to look for its target customer. This is a logical procedure. Even in the event of application of four attributes - Peculiarity, Diversity, Vitality and Resourcefulness - described and established through research by Ol'ga Gyarfášová and Marián Timoracký in their research The Branding of Slovakia; Od ideového konceptu k posolstvám a komunikácii (From Ideological Concept to Legacies and Communication) published in 2013.

A state cannot be promoted in any form if there is no product to be offered to the target customer. Martin Horváth, the first person who raised the subject of Nation Brand in Slovakia, says that any communication activities related to the brand of Slovakia are useless unless they are preceded by responsible work with the topic of the brand, i.e., the product. First of all, it is necessary to establish the type of product of Slovakia in an international scale and whether the country is consumable as a product. If individual parameters are competitive, it is possible to assume that communication reaches the recipient interested in it and that it corresponds with his/her requirements. In other words: is the country a relevant 
product on an international scale.

At the end of the communication, there must be something for the target customer to consume - something of a physical or psychological nature. According to existing studies carried out for the purposes of the Nation Branding of Slovakia, what Slovaks perceive as the landmarks of this country that should be presented has been defined, but none of these studies has an answer to the question of why new tourists should visit our country or why foreign companies should invest here, or the system changes which should take place so that we can be perceived more positively abroad, since the creation of a country brand incorporates many aspects which need to be applied - Hexagon or the matrix designed by Simon Anholt for Nation Brand.

\section{Comparison with Branding of Poland}

Let's take the example of Poland for the sake of comparison. The rebranding of Poland was set for the period from 2008 to 2015. Since 1989, Poland, as an independent state, also underwent a twenty year period in which they hired experts for the Nation Brand of Poland. One of the baselines was the unifying of the graphic visual designs which always differed up to that point (for example, their logo was completely different for each EXPO year, which is also true for Slovakia). Poland built their branding on their environmental policy. In his study for Poland, Wally Olins considered the depiction of Poland as a country that is located in the East but which understands the West. Poland in general could be a bridge between West and East. But Poland decided to go for the country people do not know. The product that visitors and investors will acquire is a young unknown country with great opportunities and a market open to the West and East. The traditional culture of the East with services for the West; a cheap but well trained labor force and a stable economic and political background. Poland clearly specified and classified and began to present itself in a unified way. Pope Karol Wojtyla, who was of Polish origin, distinctively helped the Poles in building their country brand in the second half of the $20^{\text {th }}$ century. According to Modrzejowski and Gálik (2014, p.1), "Wojtyla shaped the principle communio personarum (community of persons), which maintains the realization of universal community including all mankind. "The human I in these different dimensions [family, society, nation - A.M., S.G.] carries a readiness not only to think about oneself in the category we but to realize what is important for us - a social community, and also on the grounds of this community, according with its human nature readiness to realize the subjectivity of many, into an universal dimension." Such perception of society fully corresponds with the conclusions of Simon Anholt, who understands the collective good as the basic principle in building a country brand.

\section{Conclusion}

Slovak Republic, or the institutions founded pursuant to the Slovak laws, act independently and are not coordinated. The presidency of Slovakia is proof of that (the presidency rotates between the European Union member states on a semiannual basis), when the MoFEA SR, as an institution representing Slovakia towards foreign countries, must arrange all of the activities leading to the successful implementation of the Slovak presidency and like every other country, the creation of the logo of this presidency. The only condition for the logo from the European Council is that it correspond with the logo of the Council pursuant to established specifications. There is no such condition from the party of Slovakia. So this logo once again will not correspond with the already designed logo types or basic symbols of Slovakia. However the MoFEA SR would like to begin to promote the Slovak brand during the Slovak presidency. But it is not at all clear how or what will be communicated, even if the course of action of the Ministry is correct. However, Simon Anholt does not recommend presenting the Nation Brand through such events. During its presidency, Slovakia will not manage to present any new theme (in such short notice) that would correspond with the established new country brand; moreover, any activity would remain in the background (suppressed) by the presidency itself and by the method of negotiations. Thus, all efforts may be wasted.

Based on all of the presented factors, it is questionable if the MoFEA SR is prepared to transfer the topic of Nation Brand from academic grounds and begin to apply it in the everyday life of this country. Are the priorities and procedures incorporated in public procurement set up correctly? Should the MoFEA SR, as the institution responsible for design of the Slovak nation brand, consider the last steps and consult them with experts who have already created or re-created the Nation Brand of countries? Since we're talking about the money of common citizens - tax payers, many people will follow this process and therefore this recommendation is fully justified. 


\section{References}

Zaušková A. (2010). Nástroje pre zvyšovanie inovačnej výkonnosti a konkurencieschopnosti regiónov, (Tools for improving innovation performance and competitiveness of the regions) In Communication today, FMK UCM v Trnave, vol. 1, No. 1, p. 43.

Bobovnický A. Destination branding and the impact of perceived quality and image on the loyalty, In Communication today, FMK UCM v Trnave, vol. 2, No. 1, 2011, p. 86.

Modrzejewski A., Gálik S. "Karol Wojtyla's personalistic and universalistic philosophy of culture," in European Journal of Science and Theology, Vol.10, No.4, 2014, p. 1

Branding SR: management of public debate in communications and messages of created visual depiction in branding. A study carried out for the purposes of the Ministry of Foreign and European Affairs of the Slovak Republic. FMK UCM in Trnava, 2014

Branding SR: transforming an idea concept into visual signals, creation of visual solutions, FMK UCM in Trnava, 2013 